Review

\title{
Urban Water Tariffs in Spain: What Needs to Be Done?
}

\section{Miguel A. García-Rubio ${ }^{1,2, \dagger}$, Alberto Ruiz-Villaverde ${ }^{1, \dagger, *}$ and Francisco González-Gómez ${ }^{1,2, \dagger}$}

1 Department of Applied Economics, University of Granada, Campus Cartuja s/n, Granada 18011, Spain; E-Mails: magrubio@ugr.es (M.A.G.-R.); fcojose@ugr.es (F.G.-G.)

2 Water Research Institute, University of Granada, C/ Ramón y Cajal, 4, Granada 18071, Spain

$\dagger$ These authors contributed equally to this work.

* Author to whom correspondence should be addressed; E-Mail: albertorv@ugr.es; Tel.: +34-958-243732; Fax: +34-958-249380.

Academic Editor: Markus Disse

Received: 19 January 2015 / Accepted: 9 March 2015 / Published: 31 March 2015

\begin{abstract}
Recently, in the context of the Integrated Water Resources Management, demand policies are playing a more important role as opposed to traditional supply policies based on the construction of large hydraulic infrastructures. In this new context, water tariffs have become an important tool in achieving economic efficiency, environmental sustainability, and social equity. This paper reviews the situation of urban water tariffs in Spain, a country subject to high water stress. It analyzes the capacity of urban water tariffs to recover service costs and to promote efficiency, sustainability, affordability, and equity. Although it has made significant progress in recent years, the Spanish urban water tariff system still faces many challenges. Many of these challenges would be better addressed by a national independent regulatory body.
\end{abstract}

Keywords: water pricing; urban water services; cost recovery; efficiency and sustainability; affordability; fairness and equity

\section{Introduction}

According to the Principles of the Conference on Water and the Environment held in Dublin in 1992, fresh water is considered a finite and vulnerable resource, essential to sustain life, development, and the environment, and is considered an economic good. Since then, water has developed from being a simple 
factor of production to an eco-social asset, with the capacity to satisfy a range of economic, social, and environmental functions [1]. Thus, compared to traditional water policy focused on the construction of large hydraulic infrastructures, the international community recognizes the need to implement policies for Integrated Water Resources Management, and water demand policies have become important.

In urban areas, among the set of demand measures, water tariffs play an important role in water policy. In fact, water tariffs are seen as an economic policy tool for the simultaneous achievement of various objectives. Urban water tariffs should primarily fulfill three main objectives [2]: (1) Provide sufficient income to recover all costs associated with the service; (2) Promote efficient and sustainable water use; and (3) Facilitate universal and equitable access to the service. In more detail, tariffs should promote conservation of scarce resources and provide the required revenue to support the utility's operations, activities maintenance, pay-as-you-go capital outlays, and debt service. With regard to economic efficiency, tariffs should promote patterns and levels of water use that tend to minimize the total cost of meeting the service area's water needs. Regarding water access, tariffs should also be fair and equitable [3] and be perceived by different users of water services as fair and equitable. This implies that in the case of equivalent services costs, the price charged to the user must be equal. Reconciling these objectives from a single instrument is a difficult challenge [4-6].

In parallel to the importance placed on prices for water management, research exists that focuses on the analysis of tariff design for the attainment of the above objectives. For example, the water pricing design to achieve cost recovery can be consulted [7,8]. The relationship between service costs and water prices has been analyzed in $[9,10]$. The design of optimal prices for the urban water distribution service in terms of efficiency and sustainability is examined in [11,12]. Finally, how to design water tariffs considering affordability has been discussed in [13,14], and the equity has been treated in $[15,16]$.

From the emphasis on price as a tool of water policy and the research produced around the design of optimal water tariffs, developed countries have made changes to their pricing policies. Generally, a system of two-part tariffs has been imposed, with a fixed connection fee and a variable or volumetric consumption fee [17-19]. The question is whether or not in recent years these countries have made sufficient efforts to adapt their water tariffs to the guiding principles of efficiency, sustainability, and equity.

This article analyzes the Spanish case-A country with water scarcity throughout most of its territory and requiring improved water demand management [20]. In Spain, the possibility of increasing the availability of water resources by means of large hydraulic infrastructures has been exhausted. The number of reservoirs grew at the rate of more than 4 per year between 1900 and 1950, before almost doubling to reach 741 units by 1975. By 1990, this figure had more than doubled again (19.5 per year). Today, there are 1172 large dams [21]. Therefore, alternative measures such as non-conventional water resources and pricing policies must be considered [22]. Although water to urban areas represents only $15 \%$ of water used in Spain and measures for better water management should be directed primarily at agriculture, improvements in water use are also required within cities. This paper conducts a critical analysis of the urban water tariff design in Spain and an evaluation in regards to the objectives of economic efficiency, environmental sustainability, and social equity. In recent years this has been an issue investigated in Spain (Table 1). 
Table 1. Research in Spain on water prices in urban areas.

\begin{tabular}{|c|c|c|}
\hline Topic Considered & Reference & Main Results \\
\hline \multirow[t]{3}{*}{$\begin{array}{l}\text { Cost analysis and } \\
\text { water tariff levels }\end{array}$} & [23] García-Valiñas (2005a) & $\begin{array}{l}\text { The application of Feldstein's formula for setting water tariffs is } \\
\text { suggested, in so far as the Ramsey rule may go against the principle of } \\
\text { equity, primarily from the perspective of its structure. }\end{array}$ \\
\hline & [24] Barberán et al., (2008) & $\begin{array}{l}\text { Designing the water tariff structure based solely on the cost structure, so } \\
\text { that the unit price of water would be unique and approximately equal to } \\
\text { its marginal cost, is not appropriate. }\end{array}$ \\
\hline & $\begin{array}{l}\text { [25] Martínez-Espiñeira et al., } \\
\text { (2009) }\end{array}$ & $\begin{array}{l}\text { Local governments appear more likely to relinquish the management } \\
\text { when they operate under more complex environments, while private } \\
\text { firms seek to take over the service in those areas where it is easier to } \\
\text { obtain higher profits. Once the factors describing the operational } \\
\text { environment have been accounted for, it can be seen that private firms } \\
\text { set on average higher prices than public ones. }\end{array}$ \\
\hline
\end{tabular}

[26] García-Valiñas et al., (2013) Prices are lower when the urban water service is directly provided by town councils. When water services are contracted out to external companies, the prices set by public utilities are higher than the prices of private utilities. Water prices are also higher when the provision of the service has been privatized to an institutionalized public-private partnership compared to contractual public-private partnerships.

[27] Chica-Olmo et al., (2013) Nearby municipalities are found to approve similar water prices. Local governments more than likely seek to avoid citizens perceiving a comparative disadvantage in water tariff payments. However, such political interests could be detrimental to price setting aimed at promoting an efficient use of water resources and recovering costs.

[28] Bel et al., (2015) Once the contract for the provision of the service is awarded, firms with a larger market share make their dominant position effective by setting higher prices for water; thus, market concentration is associated with higher prices. The urban water service privatization must be accompanied by the appropriate regulatory and institutional frameworks to promote competition among businesses.

Affordability, [29] García-Valiñas (2005b) fairness, and equity

Feldstein's formula achieves distributional objectives without substantially reducing social welfare. That framework could provide an alternative to other mechanisms that allow equity to be achieved but are seen as inefficient, such as free allowances, or mechanisms that sometimes do not have enough diffusion or effectiveness, such as the discounts related to personal characteristics.

[30] Barberán and An increasing block water tariff to encompass the equity criterion is Arbués (2009) proposed. This water tariff consists of two increasing blocks, established so that the width of the first block and the relationship between the prices in both depend on the benchmark standard, consisting of fixed consumption per household and variable consumption per household member.

[31] García-Valiñas et al., The analysis of the factors behind the differences in the water (2010a) affordability shows that the relative cost of purchasing the basic level of domestic water use appears inversely related to average income levels, revealing a regressive element in the component of water tariffs affecting the least superfluous part of the household's consumption. 
Table 1. Cont.

\begin{tabular}{|c|c|c|}
\hline Topic Considered & Reference & Main Results \\
\hline \multirow[t]{3}{*}{$\begin{array}{l}\text { Affordability, } \\
\text { fairness, and equity }\end{array}$} & $\begin{array}{l}\text { [32] García-Valiñas et al., } \\
\text { (2010b) }\end{array}$ & $\begin{array}{l}\text { This paper proposes an alternative indicator that better reflects water } \\
\text { affordability at the municipal level. The proposed index shows that the } \\
\text { ability of households to afford a basic amount of water is relatively high. } \\
\text { Also, this index shows which of the municipalities have included "low } \\
\text { equity" criteria in the design of water tariffs, giving priority to other kind } \\
\text { of criteria. }\end{array}$ \\
\hline & $\begin{array}{l}\text { [33] Arbués and } \\
\text { Barberán (2012) }\end{array}$ & $\begin{array}{l}\text { There are equity problems associated with the size of the household, } \\
\text { particularly regarding large households. Furthermore, a large part } \\
\text { of the special tariffs for larger households adopted do not solve that } \\
\text { equity problem. }\end{array}$ \\
\hline & $\begin{array}{l}\text { [34] Martínez-Espiñeira et al., } \\
\text { (2012) }\end{array}$ & $\begin{array}{l}\text { Some of the differences in the price of water for residential uses among } \\
\text { Spanish cities are due to arbitrary decisions made by policy and business } \\
\text { decision-makers, so it is recommended that a regulation } \\
\text { be adopted that sets criteria for guidance in tariff design, especially } \\
\text { for lower levels of consumption. }\end{array}$ \\
\hline \multirow[t]{2}{*}{$\begin{array}{l}\text { Efficiency and } \\
\text { sustainability }\end{array}$} & [35] Roibás et al., (2007) & $\begin{array}{l}\text { Supply cuts are regressive in the sense that the higher the level of } \\
\text { household income, the lower the effect of the cut. Price rises lead to } \\
\text { lower welfare losses than interruptions but the difference between these } \\
\text { losses is relatively small. The welfare loss is larger under a supply } \\
\text { interruption than with price rises. }\end{array}$ \\
\hline & [36] Suárez-Varela et al., (2015) & $\begin{array}{l}\text { The tariff escalation is influenced by factors related to the environment } \\
\text { in which the service is supplied-Water scarcity, size of the } \\
\text { municipality, and level of economic activity-As well as by factors } \\
\text { related to the decision-makers' own strategic choices, e.g., length of time } \\
\text { in office of the ruling municipal party and decision to form a } \\
\text { supramunicipal consortium. Standards and controls should be } \\
\text { established at least at the watershed level to regulate the design of water } \\
\text { rates for residential uses. }\end{array}$ \\
\hline
\end{tabular}

Note: Only articles published in international scientific journals have been considered. Source: Own elaboration.

Despite the significant progress made throughout Spain, many challenges still remain in regards to pricing policy. The main contribution of this paper is to show, in updated form, deficits in the water tariffs design of Spain, as well as to provide suggestions to improve the tariff policy in urban areas.

Following this introduction, Section 2 describes the general framework of urban water supply management in Spain, with special emphasis on water tariff issues. Section 3 focuses on the ability of urban water tariffs to recover costs. Section 4 shows an analysis of the capability of water tariffs as an economic policy tool to promote efficiency and sustainability. Section 5 focuses on the issues related to affordability, fairness, and equity in urban water services. Finally, in Section 6, conclusions and recommendations are provided.

\section{Urban Water Management in Spain}

In Spain, urban water supply, sanitation and wastewater treatment services are under municipal jurisdiction-Articles 25 and 26 from Law 7 (2 April 1985), Regulating Local Regime Basis. To take 
advantage of scale economies, many municipalities have opted for a model of joint management; according to the Federación Española de Municipios y Provincias [Spanish Federation of Municipalities and Provinces], 325 groupings of municipalities provide wholesale or retail water services [37].

These services can be managed directly or indirectly. On the one hand, direct management can be performed by the municipality itself by means such as in-house provision or municipal associations, a local autonomous entity, or a commercial company whose social capital belongs entirely to the municipality or public company. On the other hand, indirect management can take the form of a concession, i.e., a contractual public-private partnership, or a commercial company whose social capital partially belongs to the municipality; institutional public-private partnership; and less frequently, interested management, agreements or leasing. Around $23 \%$ of Spanish municipalities supply their urban water services by some form of legally regulated private management; however, this percentage increases to $55 \%$ when expressed in population terms [38].

In Spain, regardless of the form of management, tariffs must be approved by the public administration. The Municipal Council approves the tariffs in $96 \%$ of Spanish municipalities with the remaining cases approved by a municipal association [39]. Prices are lower when urban water services are directly provided by the municipality. On the contrary, the pricing of water services is higher when contracting out to external companies [26]. Private companies also set, on average, higher prices than public companies [25]. This could be the result of "regulatory capture." In addition, when the economic compensation for services is not established as a fee, $73 \%$ of municipalities submit the tariff changes for approval by the corresponding Price Committee (PC). When urban water supply service is provided by the municipality (in-house provision) the economic compensation is that of a local tax or fee, hence tariffs approbation is not subject to the supervision of the PC. The PCs are administrative bodies of the Regional Administration whose function is to control water tariff increases. PCs only allow increases in water tariffs over the inflation rate when there are changes in production or marketing costs. However, PCs are not specific supervisory bodies for urban water services. On the one hand, the tariffs for sewerage and wastewater treatment are not under supervision. On the other hand, PCs also have competency to regulate urban transport tariffs.

The total water bill usually includes all water and wastewater service-related costs, as well as unrelated costs such as solid urban waste collection in some cases. The bill also comprises of a value-added tax (VAT) in cases where the urban water services are provided by a public company or contractual and institutional public-private partnership. Finally, in some Autonomous Communities, the water bill includes tax charges pertaining to urban water services (i.e., the improvement rate in Andalusia, the water rate in Catalonia, and the wastewater treatment rate in Extremadura). Figure 1 shows the average prices of urban cycle services in each Spanish province, distinguishing between water supply and sewage-wastewater treatment services. 


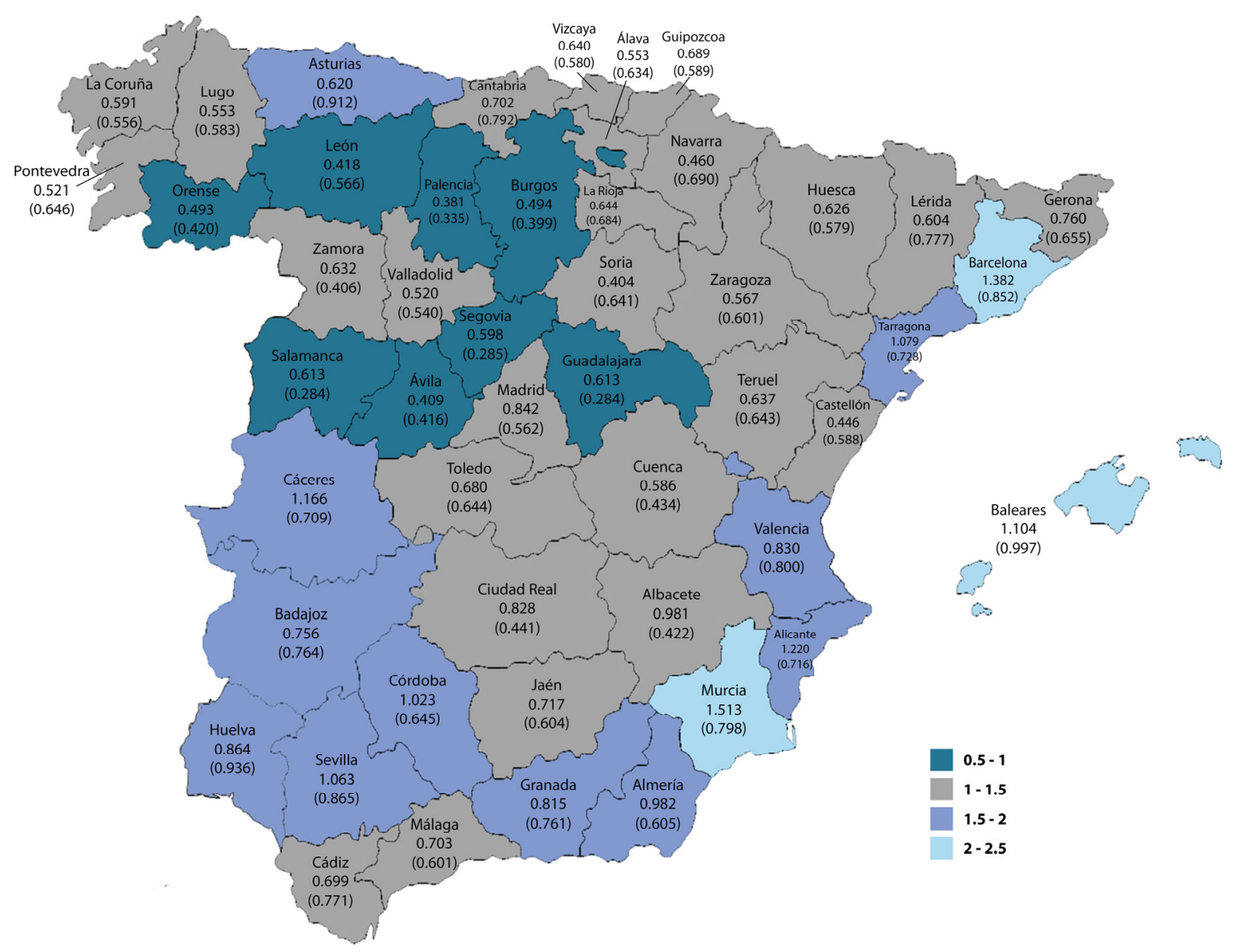

Figure 1. Average price of urban water cycle (in $€ / \mathrm{m}^{3}$ ) by province. Note: The figures without parentheses indicate the average price supply service. Figures in parentheses show the average price of sanitation and wastewater treatment. Source: Own elaboration from [40].

The most frequently employed tariff model is the two-part tariff composed of fixed and variable fees. However, there is wide variability among municipalities in the two-part tariff structure that is not always justified. Variation exists in terms of the ratio between the fixed and variable fees, the number of blocks of the variable fee, the upper and lower boundaries of the blocks, and the unit price of each block. In relation to the fixed part of the tariff, a service fee is applied to $91.3 \%$ of the population (i.e., a fixed amount of availability regardless of consumption) and a minimum consumption fee is applied to $5.7 \%$ of the population (i.e., billing for a minimum volume of water whether consumed or not, from which the water volume consumed is billed). Therefore, the absence of a fixed quota reaches only $2.9 \%$ of the population. With regard to the number of consumption blocks in the variable part of the tariff, $54.7 \%$ of the population supplied is billed using a three block consumption tariff, $35 \%$ is billed using a four block tariff system, and $5.1 \%$ receives a two block system. Hence, flat-rate water tariffs occupy a residual position provided to $5.2 \%$ of the population [40].

Billing periods are not homogeneous throughout the territory. Bimonthly bills are supplied to 53\% of users, while $45 \%$ receive quarterly bills. However, in municipalities with fewer than 50,000 inhabitants, quarterly billings are more frequent and supplied to $71 \%$ of users as opposed to bimonthly at $23 \%$. Quarterly billing predominates in Inland River Basins of Catalonia, Inland River Basins of the Basque 
Country, and the Duero and Miño-Sil River Basins, while bimonthly billing is more frequent in Tajo River Basin [39].

Water meters are a well-established method in Spain for billing users' consumption. The only consumption not usually measured is that not subject to billing, such as municipal buildings and hydrants in parks and gardens. However, the problem is that many Spanish municipalities contain old meters, which increases measurement errors. In Spain, 27\% of metering installations are older than 10 years [39].

Average prices of urban water cycle services, which are estimated by dividing the annual billing of services and the volume of water services billed, are found to be higher in the river basins, which have lower levels of rainfall (Figure 2). Average prices also tend to be higher in those river basins where less use is made of surface water source and, therefore, underground sources or desalination of seawater are more prevalent. Overall, the surface water source is the most common (77\%), followed by groundwater $(18 \%)$ and water obtained by desalination processes (5\%); however, in municipalities of fewer than 50,000 inhabitants the use of groundwater is higher (44\%) as well as desalination water sources (15\%) [39]. In Peninsular Spain, water desalination is concentrated on the Mediterranean coast.

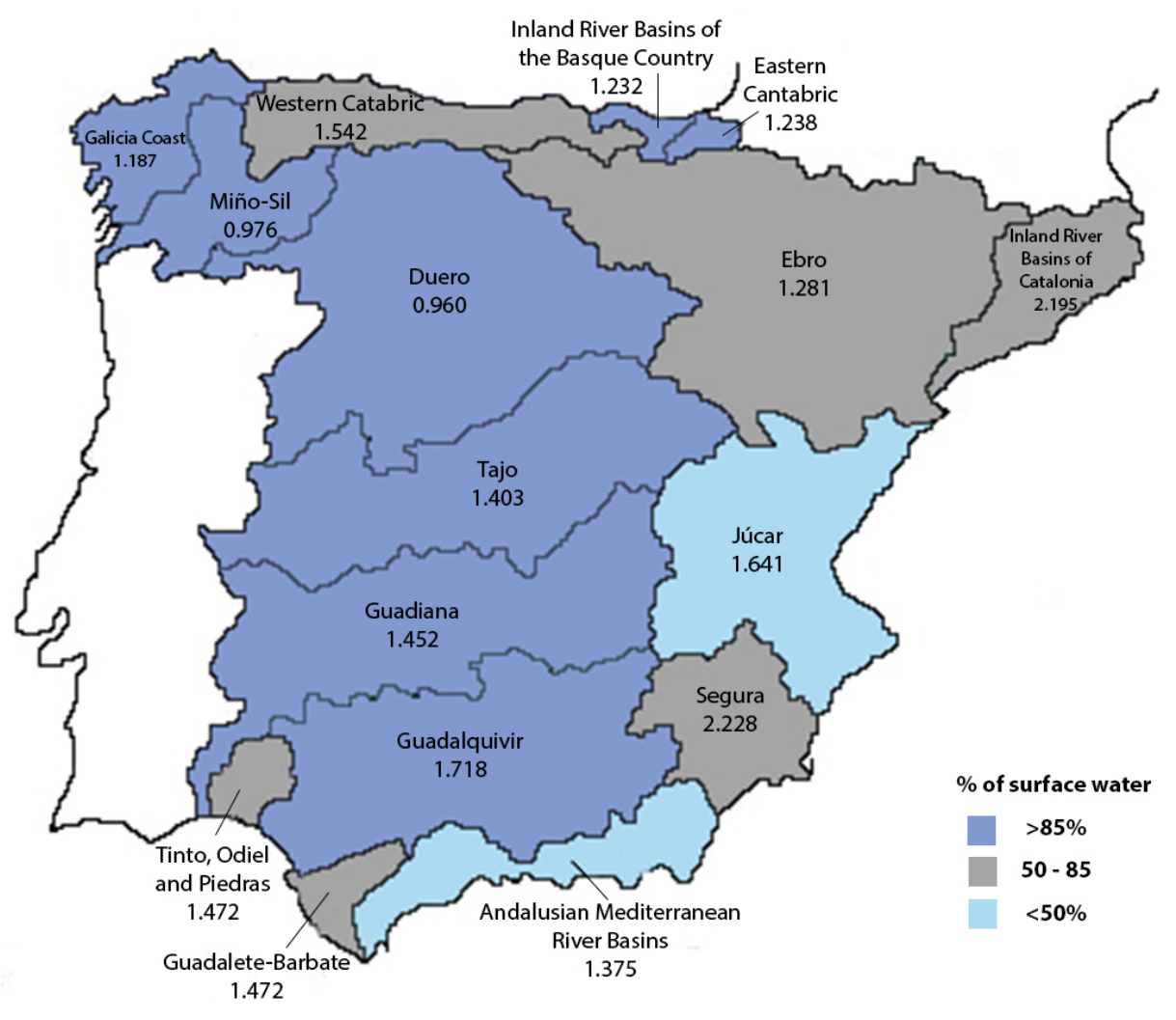

Figure 2. Average price of urban water cycle (in $€ / \mathrm{m}^{3}$ ) and water source in the peninsular Spanish River Basins Districts. Source: Own elaboration from [39,40].

Currently, there is no clear direction on water policy by the national government. There is a pending promise of approval for a National Hydrological Plan to ensure the water supply in sufficient quantity and quality, with the agreement of solidarity and support of all regions. The initial position of the current government of Spain was favorable to recovery projects of water transfers among river basins already planned in 2000 . However, the government soon became reluctant due to the costly maintenance of projects initiated by the previous government based on non-conventional sources of water 
such as desalination and water reuse. The political and territorial conflicts associated with water transfers policy, and the disagreement of the European Union with the underutilization of desalination facilities financed with the European Regional Development Fund, represented a brake on the initial attempts of the current government. Confronted with the inability to approve a National Hydrological Plan to trace the main lines of water policy in the country, the Ministry of Environment has focused in recent years on the drafting of the River Basin Management Plans (RBMP).

\section{Cost Recovery}

In the EU Water Framework Directive (WFD), establishing a framework for community action in the field of water policy, principles, and economic instruments is particularly important [41]. Under Article 9 of the WFD, the principle of cost recovery and pricing policies should take greater prominence in national policies for better management of water resources. According to the cost recovery principle, including environmental and resource costs generated by water use, funding for the provision of urban water cycle services must be assumed by the citizen as a service user, and not as a taxpayer. When the service beneficiary is paying, the cross-subsidies are avoided, resulting in a more efficient and sustainable use of water resources [42].

According to the WFD, member states were obligated to publish the RBMP, which included a report on the economic issues of the river basins. This economic report discusses cost recovery on urban water services. Table 2 shows information on the cost recovery of urban water services in the Spanish River Basins. Similar information on the recovery rate for drinking water services in Greece can be observed in [43]. However, this information should be treated with caution as there is no common methodology to estimate cost recovery both in Spain or the European Union; and in many cases, information is limited.

Table 2. Cost recovery of urban water services per Spanish River Basin ${ }^{1}$.

\begin{tabular}{cccccc}
\hline River Basin & $\begin{array}{c}\text { Total } \\
\text { Inhabitants }\end{array}$ & $\begin{array}{c}\text { Number of } \\
\text { Municipalities }\end{array}$ & $\begin{array}{c}\text { Urban Water } \\
\text { Use (\%) }\end{array}$ & $\begin{array}{c}\text { WEI }^{2} \\
\text { Cost Recovery for } \\
\text { Urban Use (\%) }\end{array}$ \\
\hline Miño-Sil & 858,310 & 182 & 13.1 & 0.037 & 33.9 \\
Eastern Cantabric & 439,675 & 122 & 54.8 & 0.091 & 39.0 \\
Western Cantabric & $1,679,331$ & 190 & 39.0 & 0.032 & 43.0 \\
Duero & $2,205,123$ & 1,945 & 5.6 & $0.318 *$ & 46.0 \\
Galicia Coast & $2,036,770$ & 157 & 25.9 & $0.252 *$ & 48.0 \\
Ebro & $3,226,921$ & 1,623 & 4.4 & $0.516 * *$ & 57.0 \\
Tajo & $1,412,198$ & 107 & 55.3 & 0.061 & 78.5 \\
Inland River Basins of the Basque Country & $7,879,123$ & 1,091 & 28.8 & $0.460 * *$ & 79.0 \\
Guadiana & $6,634,030$ & 312 & 50.6 & $0.319 *$ & 81.0 \\
Guadalquivir & $1,472,800$ & 473 & 5.2 & $0.459 * *$ & 81.0 \\
Andand River Basins of Catalonia & $4,107,598$ & 476 & 13.0 & $0.629 * *$ & 84.5 \\
Júcar & $2,424,620$ & 249 & 18.4 & $0.490 * *$ & 84.7 \\
Guadalegura & $5,177,061$ & 751 & 19.2 & $0.542 * *$ & 86.0 \\
Tinto, Barbate & $2,006,794$ & 137 & 9.2 & $0.788 * *$ & 88.0 \\
\hline
\end{tabular}

Notes: ${ }^{1}$ Canary Islands and Balearic Islands are not included; ${ }^{2}$ Water Exploitation Index; ${ }^{*}$ stressed;

** severe stress. The Water Exploitation Index is the mean annual total abstraction of freshwater divided by the mean annual total renewable freshwater resource at the river basin level. Source: Own elaboration from River Basin Management Plans 2010-2015. 
Information on costs and revenues is generally scarce. However, when available, each agency involved in management may record this information differently. All Spanish RBMP include operating, maintenance, and administration costs and also normally include amortization costs of infrastructure. However, not all investment costs are always considered. Some RBMP exclude non-refundable investment costs - Capital grants - as they are not added to user tariffs, which results in higher cost recovery figures. It should be noted that the WFD does not necessarily require that all costs are recovered, but it demands transparency regarding the costs and revenues of the water services. From this viewpoint, the investment costs should be included regardless of their origin. Moreover, investment costs are estimated differently depending on the legal status of the entity providing the service - in house provision, public company, and institutional or contractual public-private partnership; and, to make matters worse, the total investment costs are not always available.

Environmental and resource costs are not included when assessing cost recovery. Environmental costs in Spain are identified as the cost of those measures necessary to prevent, avoid, mitigate, or repair damages. Although it is less expensive than consumer preferences valuation, this approach tends to underestimate the environmental damage, as in some cases the damages cannot be fully repaired $[44,45]$. If environmental damage is irreversible, the economic analysis becomes irrelevant and unable to calculate something that is immeasurable; therefore, the WFD should make clear that there are inalienable ecological principles, and should denote which environmental costs are unacceptable. Recently, the European Commission recognized the need to develop a guidance document that focuses on methodology to assess the cost and benefits of water measures supporting cost-effectiveness and further implementation of the concept of payment for ecosystem services [46].

Therefore, carefully considering the data on cost recovery of urban water services in Spain, Table 2 shows significant differences in the degree of cost recovery between the various Spanish River Basins. The cost recovery levels range from 33.9\% in the Miño-Sil River Basin to 95.4\% in the Tinto, Odiel, and Piedras River Basins. Therefore, relatively high prices can be compatible with low levels of cost recovery, e.g., in the Western Cantabric River Basin. In areas in which the Water Exploitation Index (WEI) is higher, a greater recovery of water services cost can be observed (Table 2). However, in these river basins there are no water conservation taxes [47]. In Spain, only in exceptional cases and in drought years, a drought levy is applied to the water bill in order to deter high water consumption levels. This drought levy disappears with increasing rainfall. Furthermore, paradoxically, the supply of desalinated water is more concentrated in more highly stressed river basins located on the Mediterranean coast [48]. The operation of desalination plants below their maximum capacity and the increasing energy prices in recent years have increased the average cost of desalinated water, which complicates cost recovery compliance [49].

There are several reasons for the breach of the cost recovery principle in Spanish urban water services. Firstly, the investment and infrastructure maintenance costs of wholesale water services, which include abstraction, transport, and storage, are usually financed by the public budget, charging only part of the total costs to the end user. In Spain, there is a subsidy system implicit in water consumption [50]. Therefore, it is difficult to accurately determine the cost of wholesale water services. In the construction of wholesale water infrastructure, it is common to identify funding from various administrations: Provincial Government, Regional Government, National Government, or the European Union. Hence, this creates a complex network of subsidies for infrastructure. The situation becomes more complex when the infrastructure is shared among different uses, e.g., regulation and transport of raw water for populations, energy uses, and 
irrigation. In these cases, therefore, it is necessary to allocate costs among different uses. It is possible that the cost of wholesale water services allocated to users represents a small percentage of the total cost of urban water services; Nevertheless, this does not mean that the allocated amounts of the canon de regulación (regulation charge) and the tarifa de regulación del agua (charge for water use) cover the real costs of the wholesale water infrastructure service. According to the Ministry of Environment [51], non-attributable investment costs represent more than $24 \%$ of total capital costs. In fact, in many cases those charges do not cover capital costs, and are often insufficient to meet current or maintenance costs [52].

Secondly, although the cost recovery for retail water services is virtually complete in large and medium municipalities, problems exist in financing urban water services in less populated municipalities. According to the Spanish Environment Ministry [51], the largest deviations usually occur in less populated municipalities where investment costs funded by the government are not recovered. Furthermore, the deteriorating infrastructure financed with subsidies is not considered, so the depreciation endowment of these assets is not made. In Spain 75\% of municipalities have a population of fewer than 2000 inhabitants, with only $7.3 \%$ of the Spanish population living in these municipalities. To extend to these municipalities the quality levels of supply and sanitation similar to those of larger municipalities, disproportionate costs would arise. It is precisely in these municipalities where water losses reach higher levels. Furthermore, although the construction of wastewater treatment plants has been publicly funded, it is quite common not to commence operation in order to avoid the exploitation costs of the wastewater treatment service. In these circumstances, it can be difficult to achieve the principle of full cost recovery.

However, the main stumbling block for cost recovery is the political resistance to increased water tariffs. In Spain, tariff revisions are usually conducted annually. However, local governments, in their role as supervisors of water prices, have mainly been concerned with ensuring prices do not increase at a faster rate than the Consumer Price Index [50]. Water tariff increases above the inflation rate are more frequent when urban water management is privatized, e.g., after water services privatization in Huelva, La Union or Avilés, water tariffs increased $64 \%, 75 \%$, and $70 \%$ respectively. When this happens, the concessionaire must recover the licensing fee paid to the municipality through the water bill when it takes over the service. Unfortunately, Spanish legislation does not require that the licensing fee be invested in the urban water cycle. Hence, privatization is seen as an option for extra funds to cope with the financial needs of the municipality [38]. Increasing the urban water services price is very unpopular and often considered political suicide. In fact, geographically neighboring municipalities approve similar water prices [27]. In this manner, it is likely that local governments are seeking to avoid citizens perceiving a comparative disadvantage in water tariff payments. Nevertheless, although in most municipalities urban water services are satisfactory, prices will need to increase in coming years to ensure continued quality service [52,53] and begin to correct the infrastructure deficit affecting urban water services in Spain.

Regarding urban wastewater treatment, Spain is at a level comparable to the average of EU countries in relation to conventional treatment systems. However, there is a lack of wastewater treatment in relation to sensitive areas and small and medium-sized agglomerations, which is where efforts should be placed in the coming years [54]. With regard to the conservation condition of the urban water distribution networks, $38 \%$ are more than 30 years old [39], and non-revenue water exceeds $25 \%$. The situation is even worse in smaller population centers (see Table 3); in municipalities of fewer than 50,000 inhabitants $10.24 \%$ of the distribution networks are in poor condition (which means that the water distribution network has frequent breakdowns, damage, loss, or leakage) representing more than 11,500 km of pipelines, and more 
than 20,000 km are in fair condition [55]. Moreover, frequent stoppages in water supply to repair breakages, which occur due to the poor condition of the networks, lead to a welfare loss. In Spain, the welfare loss is larger under a supply interruption than price rises [35].

Table 3. Condition of water supply networks in Spanish municipalities with fewer than 50,000 inhabitants $(2012)^{\text {a }}$.

\begin{tabular}{ccccccc}
\hline Inhabitants & $\begin{array}{c}\text { Number of } \\
\text { Municipalities }\end{array}$ & $\begin{array}{c}\text { Total } \\
\text { Inhabitants }\end{array}$ & $\begin{array}{c}\text { Length of Supply } \\
\text { Networks (km) }\end{array}$ & \multicolumn{2}{c}{ Condition of Supply Networks (\%) } \\
\cline { 5 - 7 } & 3,108 & 571,809 & $11,295.706$ & Good & Fair & Bad \\
\hline$<500$ & 775 & 549,587 & $7,664.652$ & 72.99 & 14.97 & 12.04 \\
$500-1,000$ & 917 & $1,478,225$ & $16,609.777$ & 70.93 & 17.92 & 11.15 \\
$1,000-2,500$ & 530 & $1,894,291$ & $16,330.020$ & 76.58 & 14.68 & 8.74 \\
$2,500-5,000$ & 392 & $2,738,559$ & $18,365.487$ & 73.69 & 16.68 & 9.62 \\
$5,000-10,000$ & 318 & $5,081,721$ & $27,778.933$ & 69.59 & 20.76 & 9.66 \\
$10,000-25,000$ & 110 & $3,665,125$ & $14,508.239$ & 68.31 & 20.68 & 11.01 \\
$25,000-50,000$ & 6,150 & $15,979,317$ & $112,552.814$ & 71.98 & 17.79 & 10.24 \\
Total & &
\end{tabular}

Note: ${ }^{\text {a }}$ The municipalities of Catalonia, Madrid, Navarre, and Basque Country are not included. Source: Own elaboration from [55].

In any case, the necessary increase of urban water tariffs should be gradual and progressive over time; and should protect households at risk of social exclusion by ensuring access to water resources. However, in the absence of a national regulatory body establishing water tariffs based on objective technical criteria, relaxing local governments' political control of urban water prices will be difficult in the current circumstances.

\section{Efficiency and Sustainability}

Spain is one of the European countries most subjected to increased water stress, behind only Cyprus, Malta, and Belgium [56]. While the average WEI in the EU is 0.13, in Spain this value reaches 0.29 [57]. This high water stress is due to both the relative scarcity of renewable water resources $-68.6 \%$ below EU level - and the high rates of water abstraction (55.4\% above EU level). In some Spanish regions the extent of the problem is even greater, as variability in water stress within the country is very pronounced (see Table 2). As a result of climate change this situation will likely worsen in the medium to long term. Since 1960 annual precipitation has decreased by up to $90 \mathrm{~mm}$ per decade in the Iberian Peninsula. It is not clear if the relatively minor land-use changes in the last 60 years have influenced observed precipitation trends. For the 2050 horizon, simulations indicate a decrease in precipitation of between $5 \%$ and $25 \%$ and an increase in maximum temperature of between 1 and $2.5{ }^{\circ} \mathrm{C}$, depending on the season/area [58]. The projected change in annual precipitation shows a statistically significant decrease of up to 40\% in Southern Spain between 2071-2100 and 1971-2000 [59].

Against this background, urban water services are forced to adapt to an environment of increased water scarcity and, consequently, to reduce abstraction of raw water. In order to reduce water demand, it is necessary to increase efficiency in the use of water. Pricing policies can change users' behavior and reduce leaks in the network of water supply [60]. According to The Organization for Economic Co-operation and Development (OECD) [20], Spain should make greater use of water pricing signals to assist in ensuring 
water resources are allocated efficiently and sustainably. The question is, are urban water tariffs in Spain designed to fulfill these purposes?

In Spain, the most common water tariff structure is the two-part tariff with increasing blocks, which is adequate from an environmental perspective in helping to solve scarcity problems [20]. The water demand effect of switching from uniform rate pricing to fiscally neutral increasing block rate water budgets is estimated in [61]. Results show that three years after the change in the rate structure under water budgets, the demand was $17 \%$ lower that it would have been under a comparable uniform rate price structure. To the extent that more complicated water budget structures are both more costly to implement and harder for consumers to understand, utilities can safely pursue relatively simpler rate structures, with perhaps only three blocks, without foregoing significant conservation opportunities. The use of a variable fee can increase the households' efforts at water conservation by way of water saving behaviors and financial investments in water [62]. However, increasing block tariffs can have serious equity effects on households [30]. Promoting efficient use of water resources requires greater rationality in the water tariff structure [63]; however, the absence of a national regulatory body makes this difficult.

The existence of a fixed charge, which is not associated with water consumption, is justified by the high fixed costs of the sector $[24,64,65]$. However, a high fixed fee may discourage the application of non-revenue water reduction policies [66]. Nevertheless, although a high fixed fee may discourage saving water, its elimination would not be efficient [67]. In Andalusia, in southern Spain, the total amount of income received by the fixed fee cannot exceed $30 \%$ of the total operating expenditures of the water supply service [68], although such limitation is unusual. Therefore, to promote efficiency in two-part tariffs, a ratio between the fixed and variable fee must be established that ensures the progressivity of billing according to water consumption. In Spain, the tariff escalation is influenced by factors related to the environment in which the service is supplied, as well as by factors related to the decision makers' own strategic choices [36]. Figure 3 shows that, for an average household water consumption of $10.8 \mathrm{~m}^{3} /$ household/month [69], the revenue collection capability of the Alicante and Barcelona water tariffs are similar. However, in Alicante users may have less incentive to introduce water saving technologies due to the comparatively high fixed fee. Moreover, in Barcelona the number of blocks is higher and the variable fee is progressive for above-average consumptions; the water tariff also discourages to a greater extent the ostentatious consumption of water. Meanwhile, in Guadalajara the fixed fee is very small but the variable fee is not sufficiently progressive, resulting in insufficient incentives for water saving. The average Spanish household water consumption has been estimated by the average water consumption per person (142 liters/person/day) and the medium family size ( 2.53 person/household). As water demand is inelastic, it is not affected by small increases in the price. Similar studies at a national level have already been elaborated for other countries facing similar problems, like Greece [70,71].

Some tariff systems provide rebates for efficient water use. In Zaragoza, a reduction of 10\% of the amount of the variable fee is applied to the tariff if consumption compared to the previous two years has experienced a decrease of at least 10\%. In Madrid there is a similar rebate; in this case, if the volume of water consumed is less than that consumed in the previous year, the variable fee will be reduced by $10 \%$ of the volume price of water saved. In Seville the variable fee is reduced by $26 \%$ in connection with the first block of consumption if it is established that consumption is less than $3 \mathrm{~m}^{3} /$ inhab/month. In other cases, municipal ordinances include restrictions on use and even penalties. In Zaragoza washing appliances with inefficient systems, as well as hosepipes, are banned. The Agència Catalana de l'Aigua 
(ACA) (Catalan Water Agency) has introduced a change in the water tariff, which penalizes excessive household consumption; the second block of the variable fee is doubled, and the third block is multiplied by five. Although these rebates and penalties apply only in some large cities, it would be beneficial if such measures were spread throughout the country.

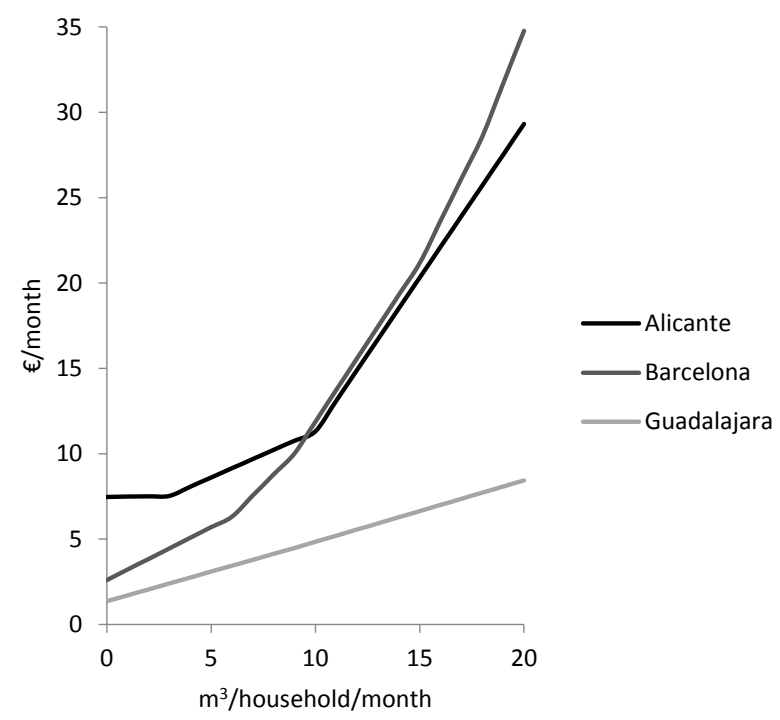

Figure 3. Water supply household tariffs comparison in three Spanish cities, 2014. Note: The fixed fee is calculated for a water meter with a caliber of $13 \mathrm{~mm}$, and a household equipped with three water points (kitchen sink, toilet, and washbasin). Source: Own elaboration from the three cities' tariffs.

More unusual still is the seasonal discrimination of tariffs, distinguishing between winter and summer. In Madrid, to discourage high consumption in summer, the household adduction tariff is higher between 1 June and 30 September. For bimonthly consumption between 25 and $50 \mathrm{~m}^{3}$, the variable fee in summer is increased by $25 \%$ from winter; if consumption is greater than $50 \mathrm{~m}^{3}$ the increase is $50 \%$. In a country with high seasonal rainfall, and a significant population increase in summer, it is likely that in the near future this measure will spread throughout most tourist areas.

Prices are crucial as these are powerful signals in triggering behavioral change in urban water users, but to be successful the water bill must be clear and transparent. In Spain in recent years, the most common billing frequency has changed from quarterly [72] to bimonthly [52], sometimes monthly for large consumers. Billing frequencies of more than once a month are justified as a way to reduce water meter reading costs; however, this makes it more difficult for consumers to monitor their household spending on water. As users perceive their remuneration each month, ideally the monthly billing would facilitate awareness of spending on water. Additionally, water bills include charges unrelated to urban water services such as urban solid waste collection. This is a tactic that excludes users from solid waste collection services in the event of non-payment. Moreover, in some cities (Madrid, Zaragoza, etc.), community water meters still exist in blocks of flats of a certain age. According to the Código Técnico de Edificación (Spanish Technical Building Code) [73], since 2006 it has been mandatory across the country for new buildings and households to each have their own water meter. Community water meters prevent the user from controlling their consumption, which also reduces awareness of the need to make rational use of water. It has been observed that by implementing individualized water meters a decrease of up to $40 \%$ in consumption can 
be achieved [74]. All these practices distort the perception of household spending on water, and in these conditions the price signals are less effective.

Finally, current water tariffs in Spain do not encourage the control of water losses in supply networks. In $[66,75]$ a comparative analysis of water pipe networks' performance from eight cases across the EU Mediterranean Basins can be seen. Given the low price of water, increasing raw water use to feed leaks may prove a cheaper managerial strategy than tracing and repairing leakages [76]. This situation is exacerbated by the low weight of investments related to the urban water cycle infrastructures in Spain, only $0.11 \%$ of GDP compared to $0.27 \%$ on average in the EU [77]; between 2008 and 2012 urban water services investments were reduced by $40.8 \%$ (see Figure 4), and the non-revenue water increased. Non-revenue water includes "real losses" such as leakage on transmission and distribution mains, leakage and overflows at utility's storage tanks, and leakage on service connections up to the point of customer metering; "apparent losses," for example, unauthorized consumption and metering inaccuracies; and "unbilled authorized consumption," which includes municipal uses such as municipal buildings, hydrants in parks and gardens, or fire hydrants [78]. With regard to this issue, a comparative analysis can be seen in [66] from areas located in four Mediterranean countries.

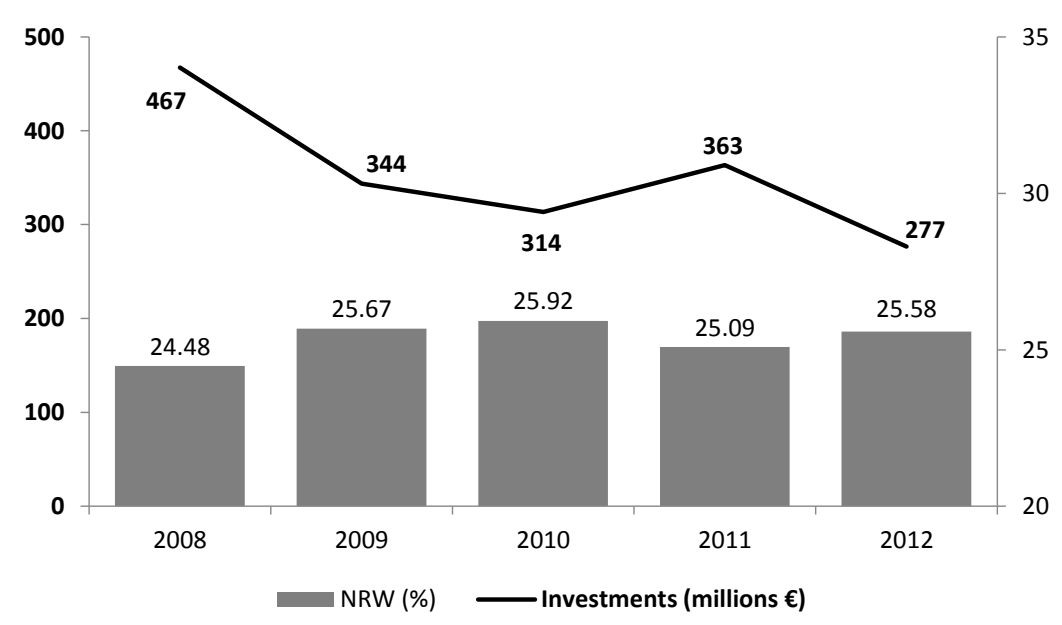

Figure 4. Relationship between urban supply services investments and non-revenue water in Spain (2008-2012). Source: Own elaboration from [67].

Water losses are economically inefficient, which implies extra energy costs and chemicals for water purification. They can also impair water quality in the distribution network, as its presence is indicative of the lack of integrity of the pipelines. Moreover, when the origin of the resource is superficial, social and environmental costs of water extraction can generate externalities reducing use benefits (recreation, landscape, fishing, etc.) and non-use benefits (conservation use of Aquatic Ecosystems) [79]. Costs may also be higher when we speak about small rivers, such as those located in southern and eastern Spain. In the case of groundwater, an excessive amount of real losses may lead to an overexploitation of the aquifer, contributing to the loss of quality of the resource at its origin. In Spain, approximately $18 \%$ of the water used for urban uses has an underground source [39]. Nevertheless, from an economic point of view, a zero water loss level can hardly be a reasonable goal. Globally, the level of water losses in Spain is 15.85\% [69], a relatively moderate figure. However, there is no law or regulation that establishes a water leakage target that the service managers in cities must achieve. Therefore, some Autonomous Communities outweigh 
this figure-24.94\% in Cantabria, 23.97\% in Extremadura, and 20.27\% in Castilla-La Mancha-and, at a municipal level, variability is even greater.

\section{Social Concerns: Affordability, Fairness, and Equity}

Access to water is essential for life, health, food supply, wellbeing, and development. Furthermore, the services associated with the essential water cycle generate positive externalities. Therefore, access to water is considered a merit good. Institutionally, the European Union recognizes water services as a service of general interest [80]. Therefore, the universal provision of water services should be ensured, even though there is no private incentive to do so, and the water price should not be an obstacle to access the service [81,82]. Furthermore, prices must be equitable across user classes [2].

Currently, access to urban water services is universal in Spain [50]. Moreover, some international statistics show that the water price in Spain is among the lowest in the developed countries [17-19]. The average water price for domestic uses is $1.71 € / \mathrm{m}^{3}$, of which $65 \%$ corresponds to water supply, $13 \%$ for sewerage, and $22 \%$ for wastewater treatment [40]. The urban water bill represents on average around $0.8 \%$ of annual expenditure of Spanish households [83]. Regardless of whether the fixed fee of the tariff reduces the instances of lower water consumption, the relatively low price of urban water proves no threat to affordability [31].

Additionally, in many Spanish cities the tariff systems provide different rebates in an attempt to face problems of social exclusion. Thus, it is possible to find rebates for low-income households, pensioners without other economic sources, and households where all members are unemployed.

In Spain, when an urban water bill is unpaid, the possibility of cutting the water supply is contemplated. Although the water bill has little weight in the average budget of households, and rebates for households with economic problems are considered, the present scenario of the economic crisis — with an unemployment rate of around $25 \%$ [84] and a risk of poverty rate of $21 \%$ [85] — causes many families difficulties in coping with the payment of the water bill. Currently, no national statistics exist on the number of households without access to water due to non-payment. However, the Instituto Nacional de Estadística (INE) (Spanish National Institute of Statistics) [85] estimates in 2013 that 9.3\% of Spanish households had delays in payment of bills related to the main dwelling such as mortgage payment, dwelling rent, water, gas, electricity, and community fees. Meanwhile, according to the Asociación Española de Operadores Públicos de Abastecimiento y Saneamiento (AEOPAS) [Spanish Association of Public Operators Supply and Sanitation] [86], in 2013 more than 500,000 service suspension notices were recorded, with $60 \%$ of these notices being executed, i.e., 300,000.

Given this situation and the growing phenomenon in other EU countries affected by the economic crisis, there have been various initiatives at the European level to ensure access to water. In February 2014 a citizens' initiative was presented at the European Parliament; it was proposed that water and sanitation services be regarded as a human right and, therefore, that a subsistence minimum water supply be universally ensured [87]. This is the first citizens' initiative presented in the European Parliament. At the time of submission to the Commission the number of signatories was 1,659,543 people. In March 2014 the European Commission adopted a weak commitment [88]: to invite member states to ensure access to a minimum supply of water to all citizens. Nationally, Izquierda Unida (IU) (United Left), a leftist party with representation in the Spanish Parliament, defends the adoption of a rule on minimum vital supplies 
for households facing the social exclusion risk. The proposal aims to ensure that households have access to 100 liters/person/day.

While these initiatives are studied, some municipalities have already adopted measures to ensure that households have access to a minimum vital supply. For example, El Prat de Llobregat guarantees through a solidarity fund access to 150 liters/person/day; or in Medina Sidonia a vital minimum supply of $3 \mathrm{~m}^{3} /$ person/month is provided by reason of social exclusion or poverty. Moreover, as is the case in the province of Huelva, there are municipalities that are committed to not cutting the water supply to a non-payer if the household faces social exclusion; in these cases, there is no cancellation of debt but the payment is deferred.

Regarding the application of fairness and equity, it is possible to make two objections. The first is the inequity suffered by large families when the tariff includes a variable or volumetric fee. As the number of family members rises, so does the household water consumption, and therefore, in the presence of increasing block tariffs large families are subject to a higher payment. That is, in large families, for the same water consumption per capita a higher price per person is applied.

Some Spanish municipalities attempt to solve this imbalance. The most widespread case is the approval of tariff rebates for large families of five or more members. However, this is not an optimal solution as the problem remains for families with one to four family members. Moreover, in most cases, the tariff rebate is identical for families with five or more family members. In any case, according to Arbués et al. [33], the tariff rebates for large families tend to benefit in excess to the families who receive them. Some municipalities reduce the blocks price of the variable fee of the bill while others increase the consumer intervals defining each block.

In Spain alternate strategies exist which take into account the differences in households; however, due to greater complexity of implementation, these strategies are less widespread. For example, in the cities of Malaga and Seville, the tariff takes into account the consumption of water per capita per month. In Zaragoza, if the number of family members is greater than six, families can request a per capita tariff. In Barcelona the system is more complex, as it considers both the type of housing as well as the number of family members. Thus, in dwellings with more water points, a higher fixed fee is applied; While considering the variable fee, the consumer intervals defining each block vary depending on the number of family members.

The second objection to fairness and equity occurs when comparing the tariffs between municipalities. In Spain water tariffs are approved by the municipality as there are no national standards on the tariff design. This situation has led to a wide variation of water tariffs throughout the country, an issue reported by consumer organizations. The latest report by FACUA (Consumers in Action), which compares the water prices in 20 Spanish cities, found differences of up to $354.4 \%$ in the water bill price for a hypothetical water consumption of $10 \mathrm{~m}^{3} /$ month [89]. This figure is $440 \%$ in a report by the Organización de Consumidores y Usuarios (OCU) [Organization of Consumers and Users] for water consumption of $25 \mathrm{~m} /$ month; in this latest report the water prices of 54 Spanish cities are compared, including all provincial capitals [90].

In any case, the equity principle does not imply that water tariffs must be the same in all municipalities; However, prices should reflect the costs of the service. The differences in the cost of water resource abstraction, purification techniques of raw water, the distance to the place of water supply, or the type of wastewater treatment may explain the differences in prices charged to the user. However, there is also 
evidence that differences in water prices in Spain can be explained in part by the ideology of the political party in the local government $[34,36]$, the type of management (public or private) $[25,26]$, and the level of market concentration in the industry [28].

\section{Conclusions and Recommendations}

For many countries, especially those where water stress exists, Integrated Water Resources Management is a major challenge for the 21 st century. In the context of water scarcity, academics and international organizations maintain that water pricing is a tool that can contribute significantly to the improved management of water resources. Economic, environmental, and social objectives can be achieved by designing tariffs. Consequently, among other measures of water policy, developed countries have recently emphasized water tariff design as a tool for managing water resources. One concern in these countries is whether the change in pricing policy has been optimal; do the current water tariffs work to achieve economic, environmental, and social objectives?

In this paper a critical review of pricing policy in Spanish urban areas has been conducted. The review provides an indication of the extent to which prices contribute to the achievement of cost recovery, efficiency, sustainability, affordability, and equity objectives. In addition, requirements are provided regarding what needs to be done in the design of urban water tariff to achieve the above objectives.

In general, the level of cost recovery for urban water services is insufficient, although the situation is worse in those river basins subject to less water stress. This is not due to the lower impact of environmental costs in these river basins, since Spanish RBMPs do not adequately contemplate the environmental and resource costs. Investment costs are not considered when financed through sunk investments or subsidies.

In addition, the wholesale water supply is heavily subsidized [50]. All this leads to a lack of transparency regarding the actual costs of urban water services, which does not assist in promoting efficiency in resource use. Moreover, the wastewater treatment services in less populated municipalities are insufficient, and an important part of the water distribution network is in poor condition, leading to significant water losses in these networks. It is therefore necessary to gradually and progressively increase water tariffs over time, to address the obsolescence of urban water infrastructures. However, this increase should not jeopardize the access to water in underprivileged households. Nevertheless, there is a strong political resistance to raising the urban water price.

In terms of efficiency and sustainability, the severe water stress experienced by most areas of the country and the expected reduced availability of water resources due to climate change require the rationalization of urban water demand. Although two-part tariffs are widespread, the low prices of urban water in Spain do not contribute to this objective or a favorable framework for reducing water losses in the distribution networks. Normally, the tariff designs do not obey rational criteria and vary excessively throughout the country; often the fixed fee is too high and the variable fee is not sufficiently progressive; marginal prices are excessively low and do not encourage water saving by users. Different types of measures to promote efficiency such as rebates for water saving, restrictions on use, and penalties for excessive consumption have been adopted in some large cities; however, in the lower populated municipalities such measures are absent. Last but not least, if water bills are clear and transparent to users, tariff policies are a powerful tool. However, in Spain, the excessively long billing frequency, the presence 
of charges outside the urban water service, and the existence of community water meters distort the perception of users regarding their spending on water.

Considering social objectives, although the amount of a water bill represents a small percentage of the average family budget, due to the current economic crisis a growing number of families cannot pay the water bill and face water cut-offs. In some municipalities a subsistence minimum water supply is guaranteed, and water cut-offs for people in vulnerable situations are prohibited. However, access to water as a human right is not yet recognized and nor is guaranteed access to a subsistence minimum water supply across the country. Although there are initiatives at the municipal level, these are not always suitable for correcting higher prices per capita, affecting the families with more members. As long as the standard practice continues, establishing water tariffs per household, not per person, this inequality will remain. Finally, there are differences in water tariffs between municipalities that are not justified by differences in costs or water scarcity; these differences are partly due to business strategies and ideological and political factors [34].

In view of these considerations, it can be stated that the urban water tariffs in Spain only partially contribute to the fulfillment of economic, environmental, and social objectives.

Regarding cost recovery of urban water services, it is necessary to improve the accessible information on costs and revenues, and homogenize the practices of recording economic and financial data by the different bodies involved in managing water resource. The public funding and subsidies for urban water services must be transparent and clear in their objectives, otherwise these may become inefficient and do not guarantee proper management of the infrastructures that have been subsidized in the past. In addition, inter-municipal management systems should be promoted to take advantage of scale economies; only then can cost recovery through water tariffs be considered in the municipalities with smaller populations.

Taking into account non-repayable grants and ignorance among managers and users of the actual cost of providing urban water services, the result is inefficient water tariff design where costs are not recovered and there is a lack of encouragement for rational use of water. In general, an increase of the variable part of the tariffs is required in order to rationalize the urban water demand. The current diversity of tariff policies of some major Spanish cities should be harnessed to identify best practices and implement these throughout the country after an adaptation and suitability analysis has been conducted for each particular situation. It is necessary to implement plans for water saving in all Spanish municipalities; in this sense, efficiency and sustainability should not only be encouraged through water tariff policies, but educational and awareness campaigns must also be implemented. Water utilities could report local average water consumption on individual bills to give households a better idea of how their own consumption compares to a relevant peer group; such information, combined with a high marginal price for excessive water use, could prove to be a highly effective approach to encouraging urban water conservation [61].

Finally, national legislation is required in order to unify pricing criteria to avoid inequities amongst types of residence. However, these criteria must leave room for prices to reflect the territory differences in water stress and cost of providing urban water service. In addition, regardless of the tariff designs, in cases of social exclusion the access to water must be ensured by means of a national rule.

However, in our opinion, all these tasks require the existence of a regulatory body similar to the Water Services Regulation Authority (OFWAT) in England and Wales or the Authority for the Regulation of Water and Solid Wastes (ERSAR) in Portugal adapted to the Spanish situation. Only a regulatory national 
body can implement the necessary reforms, otherwise urban water tariffs will fail to contribute to the achievement of the economic, environmental, and social objectives.

However, establishing an organization of this nature is not without challenges in the current Spanish decentralized framework. The ability of this organization to dictate policy regulations and judicial functions may conflict with the municipal autonomy enshrined in the Spanish Constitution and with the powers of the Autonomous Communities. These problems are not insurmountable, since the national government has legal authority for primary legislation. However, there are political problems stemming from territorial tensions in Spain. Therefore, it seems unlikely that a regulatory body similar to OFWAT or ERSAR can be established in Spain at this time. Nevertheless, the establishment of a nationwide oversight organization, even without jurisdictional or regulatory powers, would represent a significant advance in the current context. The main function of this national supervisory body would be to centralize all information from water utilities.

\section{Acknowledgments}

The authors gratefully acknowledge the constructive comments and suggestions from the anonymous reviewers. The authors also gratefully acknowledge the financial support from the following Spanish institutions: the Consejería de Economía, Innovación, Ciencia y Empleo from the Government of Andalusia (P11-SEJ-7039), the Spanish Ministry of Economics and Competitiveness of Spain (Project ECO2012-32189), and the CEI BioTIC program from Universidad de Granada (mP_CP_3). Finally, the authors acknowledge the assistance granted under the Programa de Fortalecimiento de las Capacidades de $I+D+i$, jointly funded by the European Regional Development Fund (ERDF) and the Junta de Andalucía (The Regional Government).

\section{Author Contributions}

The authors have contributed equally to the manuscript.

\section{Conflicts of Interest}

The authors declare no conflict of interest.

\section{References}

1. Aguilera-Klink, F. El agua como activo económico, social y ambiental. El Campo 1995, 132, 15-27.

2. Rogers, P.; Silva, R.D.; Bhatia, R. Water is an economic good: How to use prices to promote equity, efficiency, and sustainability. Water Policy 2002, 4, 1-17.

3. Boland, J.J. Pricing urban water: Principles and compromises. J. Contemp. Water Res. Educ. 2011, 92, 7-10.

4. Wichelns, D. Enhancing the performance of water prices and tariff structures in achieving socially desirable outcomes. Int. J. Water Resour. Dev. 2013, 29, 310-326.

5. Farolfi, S.; Gallego-Ayala, J. Domestic water access and pricing in urban areas of Mozambique: Between equity and cost recovery for the provision of a vital resource. Int. J. Water Resour. Dev. 2014, 30, 728-734. 
6. Schoengold, K.; Zilberman, D. The economics of tiered pricing and cost functions: Are equity, cost recovery, and economic efficiency compatible goals? Water Resour. Econ. 2014, 7, 1-18.

7. Kanakoudis, V.; Gonelas, K. Developing a methodology towards full water cost recovery in urban water pipe networks, based on the "user-pays" principle. Proc. Eng. 2014, 70, 907-916.

8. Kanakoudis, V.; Gonelas, K. Forecasting the residential water demand, balancing full water cost pricing and non-revenue water reduction policies. Proc. Eng. 2014, 89, 958-966.

9. Ruester, S.; Zschille, M. The impact of governance structure on firm performance: An application to the German water distribution sector. Util. Policy 2010, 18, 154-162.

10. Romano, G.; Masserini, L.; Guerrini, A. Does water utilities' ownership matter in water pricing policy? An analysis of endogenous and environmental determinants of water tariffs in Italy. Water Policy 2015, in press.

11. Monteiro, H.; Roseta-Palma, C. Pricing for scarcity? An efficiency analysis of increasing block tariffs. Water Resour. Res. 2011, 47, 1-11.

12. Hung, M.F.; Chie, B.T. Residential water use: Efficiency, affordability, and price elasticity. Water Resour. Manag. 2013, 27, 275-291.

13. Martins, R.; Cruz, L.; Barata, E.; Quintal, C. Assessing social concerns in water tariffs. Water Policy 2013, 15, 193-211.

14. Gonçalves, I.; Alves, D.; Robalo, G. Social tariffs for water and waste services in mainland Portugal: An impact analysis. Water Sci. Technol. 2014, 14, 513-521.

15. Arbués, F.; Barberán, R. Tariffs for urban water services in Spain: Household size and equity. Int. J. Water Resour. Dev. 2012, 28, 123-140.

16. Porcher, S. Efficiency and equity in two-part tariffs: The case of residential water rates. Appl. Econ. 2014, 46, 539-555.

17. The Organization for Economic Co-operation and Development (OECD). Pricing Water Resources and Water and Sanitation Services; OECD Publishing: Paris, France, 2010.

18. Global Water Intelligence (GWI). Global Water Market 2015: Meeting the World's Water and Wastewater Needs Until 2018; GWI: Oxford, UK, 2014.

19. International Water Association (IWA). International Statistics for Water Services. Statistics \& Economics; IWA: London, UK, 2014.

20. The Organization for Economic Co-operation and Development (OECD). Economic Surveys of Spain 2014; OECD Publishing: Paris, France, 2014.

21. European Environmental Agency (EEA). Reservoir and Dams. European Environmental Agency. Available online: http://www.eea.europa.eu/themes/water/european-waters/reservoirs-and-dams (accessed on 19 February 2015).

22. Fuentes, A. Policies towards a Sustainable Use of Water in Spain; OECD Economics Department Working Papers, No. 840; OECD Publishing: Paris, France, 2011.

23. García-Valiñas, M.A. Fijación de precios para el servicio municipal de suministro de agua: Un ejercicio de análisis de bienestar. Hacienda Pública Esp. 2005, 172, 119-144.

24. Barberán, R.; Costa, A.; Alegre, A. Los costes de los servicios urbanos de agua. Un análisis necesario para el establecimiento y control de las tarifas. Hacienda Pública Esp. 2008, 186, 123-155.

25. Martínez-Espiñeira, R.; García-Valiñas, M.A.; González-Gómez, F. Does private management of water supply services really increase prices? An empirical analysis in Spain. Urban Stud. 2009, 46, 923-945. 
26. García-Valiñas, M.A.; González-Gómez, F.; Picazo-Tadeo, A.J. Is the price of water for residential use related to provider ownership? Empirical evidence from Spain. Util. Policy 2013, 24, 59-69.

27. Chica-Olmo, J.; González-Gómez, F.; Guardiola, J. Do neighbouring municipalities matter in water pricing? Urban Water J. 2013, 10, 1-9.

28. Bel, G.; González-Gómez, F.; Picazo-Tadeo, A.J. Does market concentration affect prices in the urban water industry? Environ. Plan. C 2015, in press.

29. García-Valiñas, M.A. Efficiency and equity in natural resources pricing: A proposal for urban water distribution service. Environ. Resour. Econ. 2005, 32, 183-204.

30. Barberán, R.; Arbués, F. Equity in domestic water rates design. Water Resour. Manag. 2009, 23, 2101-2118.

31. García-Valiñas, M.A.; Martínez-Espiñeira, R.; González-Gómez, F. Affordability of residential water tariffs: Alternative measurement and explanatory factors in southern Spain. J. Environ. Manag. 2010, 91, 2696-2706.

32. García-Valiñas, M.A.; Martínez-Espiñeira, R.; González-Gómez, F. Measuring water affordability: A proposal for urban centres in developed countries. Int. J. Water Resour. Dev. 2010, 26, 441-458.

33. Arbués, F.; Villanúa, I.; Barberán, R. Household size and residential water demand: An empirical approach. Aust. J. Agric. Resour. Econ. 2010, 54, 61-80.

34. Martínez-Espiñeira, R.; García-Valiñas, M.A.; González-Gómez, F. Is the pricing of urban water services justifiably perceived as unequal among Spanish cities? Int. J. Water Resour. Dev. 2012, 28, 107-121.

35. Roibás, D.; García-Valiñas, M.A.; Wall, A. Measuring welfare losses from interruption and pricing as responses to water shortages: an application to the case of Seville. Environ. Resour. Econ. 2007, 38, 231-243.

36. Suárez-Varela, M.; Martínez-Espiñeira, R.; González-Gómez, F. An analysis of the price escalation of non-linear water tariffs for domestic uses in Spain. Util. Policy 2015, in press.

37. Federación Española de Municipios y Provincias (FEMP). Radiografía de las Mancomunidades en España; FEMP: Madrid, Spain, 2012.

38. González-Gómez, F.; García-Rubio, M.A.; González-Martínez, J. Beyond the public-private controversy in urban water management in Spain. Util. Policy 2014, 31, 1-9.

39. Asociación Española de Abastecimientos de Agua y Saneamiento (AEAS). Suministro de Agua Potable y Saneamiento en España XIII Encuesta Nacional; AEAS: Madrid, Spain, 2014.

40. Asociación Española de Abastecimientos de Agua y Saneamiento (AEAS). Tarifas 2012. Precio de los Servicios de Abastecimiento y Saneamiento en España; AEAS: Madrid, Spain, 2014.

41. Unnerstall, H. The principle of full cost recovery in the EU-water framework directive. Genesis and content. J. Environ. Law 2007, 19, 29-42.

42. European Environmental Agency (EEA). Assessment of Cost Recovery through Water Pricing; EEA Technical Report No 16; EEA: Copenhagen, Denmark, 2013.

43. Kanakoudis, V.; Tsitsifli, S. River basin management plans developed in Greece, based on the WFD 2000/60/EC guidelines. Desalin. Water Treat. 2014, doi:10.1080/19443994.2014.979234.

44. Kanakoudis, V.; Gonelas, K.; Tolikas, D. Basic principles for urban water value assessment and price setting towards its full cost recovery-Pinpointing the role of the water losses. J. Water Supply Res. Technol. 2011, 60, 27-39. 
45. Kanakoudis, V.; Tsitsifli, S.; Papadopoulou, A. Integrating the carbon and water footprints' costs in the water framework directive 2000/60/EC full water cost recovery concept: Basic principles towards their reliable calculation and socially just allocation. Water 2012, 4, 45-62.

46. European Commission (EC). A blueprint to safeguard Europe's water resources. In Communication from the Commission to the European Parliament, the Council, the European Economic and Social Committee and the Committee of the Regions. Available online: http://eur-lex.europa.eu/ legal-content/EN/TXT/?uri=CELEX:52012DC0673 (accessed on 27 December 2014).

47. Hoque, S.F.; Wichelns, D. State-of-the-art review: Designing urban water tariffs to recover costs and promote wise use. Int. J. Water Resour. Dev. 2013, 29, 472-491.

48. García-Rubio, M.A.; Guardiola, J. Desalination in Spain: A growing alternative for water supply. Int. J. Water Resour. Dev. 2012, 28, 171-186.

49. Del Villar García, A. El coste energético de la desalinización en el programa AGUA. Investig. Geogr. 2014, 62, 101-112.

50. González-Gómez, F.; García-Rubio, M.A.; Guardiola, J. Urban water service policies and management in Spain: Pending issues. Int. J. Water Resour. Dev. 2012, 28, 89-106.

51. Ministerio de Medio Ambiente (MMA). Precios y Costes de los Servicios del Agua en España Informe Integrado de Recuperación de Costes de los Servicios de Agua en España; MMA: Madrid, Spain, 2007.

52. Gistau, R. Contraprestación económica de los servicios de abastecimiento de agua y saneamiento: La factura del agua. Revista de Obras Públicas 2010, 157, 7-22.

53. González, J.L.; Morcillo, F. El milagro español del agua. Revista de Obras Públicas 2014, 161, $37-46$.

54. Cajigas-Delgado, A. La evolución de la depuración de las aguas residuales en España. Ing. Civil 2012, 168, 9-20.

55. Ministerio de Hacienda y Administraciones Públicas (MHAP). Encuesta de Infraestructuras y Equipamientos Locales 2012. Available online: https://ssweb.seap.minhap.es/descargas-eiel/ (accessed on 27 December 2014).

56. EUROSTAT. Water Exploitation Index. Statistical Office of the European Union. Available online: http://ec.europa.eu/eurostat/cache/metadata/EN/tsdnr310_esmsip.htm (accessed on 22 February 2015).

57. Food and Agriculture Organization (FAO). Aquastat, global information system on water and agriculture 2008-2012. Food and Agriculture Organization of the United Nations, 2012. Available online: http://www.fao.org/nr/water/aquastat/main/index.stm (accessed on 4 January 2014).

58. Turco, M.; Sanna, A.; Herrera, S.; Llasat, M.C.; Gutierrez, J.M. Evaluation of the ENSEM-BLES Transient RCM simulations over Spain: Present climate performance and future projections. Eng. Geol. Soc. Terr. 2015, 1, 199-203.

59. Jacob, D.; Petersen, J.; Eggert, B.; Alias, A.; Christensen O.B.; Bouwer, L.M.; Braun, A.; Colette, A.; Déqué, M.; Georgievski, G.; et al. EURO-CORDEX: New high-resolution climate change projections for European impact research. Reg. Environ. Chang. 2014, 14, 563-578.

60. International Council for Local Environmental Initiatives (ICLEI). Adapting Urban Water Systems to Climate Change; ICLEI: Freiburg, Germany, 2011.

61. Baerenklau, K.A.; Schwabe, K.A.; Dinar, A. The residential water demand effect of increasing block rate water budgets. Land Econ. 2014, 90, 683-699.

62. Grafton, R.Q. Household behavior and water use. OECD studies on environmental policy and household behaviour. In Greening Household Behaviour; Overview from the 2011 Survey-Revised edition; OECD Publishing: Paris, France, 2014; pp. 149-181. 
63. Kanakoudis, V.K. Urban water use conservation measures. J. Water Supply Res. Technol. 2002, 51, 153-163.

64. Kanakoudis, V.; Tsitsifli, S. Water volume $v s$. revenues oriented water balance calculation for urban water networks: The "Minimum Charge Difference" component makes a difference. In Proceedings of the IWA International Conference Water Loss, Sao Paulo, Brasil, 6-9 June 2010.

65. Kanakoudis, V.; Tsitsifli, S. Verifying the usefulness of the IWA Water Balance 2nd modification: Pinpointing the actual role of the fixed charge included in the water tariffs. In Proceedings of the 12th International Conference on Protection and Restoration of the Environment, Skiathos Island, Greece, 29 June-3 July 2014.

66. Kanakoudis, V.; Tsitsifli, S.; Samaras, P.; Zouboulis, A. Assessing the performance of urban water networks across the EU Mediterranean area: the paradox of high NRW levels and absence of respective reduction measures. Water Sci. Technol. 2013, 13, 939-950.

67. Sibly, H. Efficient urban water pricing. Aust. Econ. Rev. 2006, 39, 227-237.

68. Decreto 120/1991 (Regional Government Regulatory Law), de 11 de junio, por el que se aprueba el Reglamento del Suministro Domiciliario de Agua; Ministry of the Presidency. Regional Government of Andalusia, Seville, Spain; Regional Official Bulletin 81, 9 September 1991. Available online: http://www.juntadeandalucia.es/boja/1991/81/1 (accessed on 5 January 2014).

69. Instituto Nacional de Estadística (INE). Environment statistics. Environment statistics of water 2008-2012: Madrid, Spain, 2013. Available online: http://www.ine.es/jaxi/menu.do?type=pcaxis \&path $=\% 2 \mathrm{Ft} 26 \% 2 \mathrm{Fp} 067 \% 2 \mathrm{Fp} 01 \&$ file=inebase $\& \mathrm{~L}=1$ (accessed on 5 January 2014).

70. Kanakoudis, V.; Papadopoulou, A.; Tsitsifli, S. Domestic water pricing in Greece: A spatial differentiation. Desalin. Water Treat. 2014, doi:10.1080/19443994.2014.933616.

71. Kanakoudis, V.; Papadopoulou, A.; Tsitsifli, S. Domestic water pricing in Greece: A spatial differentiation. In Proceedings of the CEMEPE-4th International Conference, Mykonos, Greece, 24-28 June 2013.

72. Rayón, F.; Segura, X. La demanda de agua para usos urbanos. In El Análisis Económico en la Directiva Marco del Agua: Incidencias e Implicaciones para España; de la Orden Gómez, J.A., Pérez Zabaleta, A., López-Geta, J.A., Eds.; Instituto Geológico y Minero de España: Madrid, Spain, 2006; pp. 47-62.

73. Real Decreto 314/2006 (National Government Regulatory Law), de 17 de marzo, por el que se aprueba el Código Técnico de la Edificación; Ministry of Housing, Government of Spain, Madrid, Spain; Official Bulletin 74, 28 March 2006. Available online: http://www.boe.es/diario_boe/ txt.php?id=BOE-A-2006-5515 (accessed on 5 January 2014).

74. Lapeña, A. Las ordenanzas de eficiencia hidráulica como instrumento para fomentar el ahorro de agua en las ciudades. Frontera Azul. 2006. Available online: http://www.agua-dulce.org/htm /articulos/articulo9ca9.html?idarticulo=32 (accessed on 20 December 2013).

75. Kanakoudis, V.; Tsitsifli, S.; Samaras, P.; Zouboulis, A.I. Water pipe networks performance assessment: Benchmarking eight cases across the EU Mediterranean Basin. Water Qual. Exp. Health 2015, 7, 99-108.

76. Embid-Irujo, A. Water pricing in Spain. Int. J. Water Resour. Dev. 2005, 21, 31-41.

77. Global Water Intelligence (GWI). Global Water Market 2011. Meeting the World's Water and Wastewater Weeds until 2016; GWI: Oxford, UK, 2010; Volume II: Europe and Africa.

78. Farley, M.; Trow, S. Losses in Water Distribution Networks: A Practitioner's Guide to Assessment, Monitoring, and Control; IWA Publishing: London, UK, 2003. 
79. Delgado-Galván, X.; Pérez-García, R.; Izquierdo, J.; Mora-Rodríguez, J. An analytic hierar-chy process for assessing externalities in water leakage management. Mat. Comput. Model. 2010, 52, 1194-1202.

80. European Union (EU). Services of general interest. Report to the Laeken European Council. Commission of the European Communities: COM 598 final, Brussels, Belgium, 2001. Available online: http://aei.pitt.edu/45891/1/com2001_0598.pdf (accessed on 5 January 2014).

81. European Union (EU). Green paper on services of general interest: COM 0270 final, Brussels, Belgium, 2003. Available online: http://europa.eu/legislation_summaries/competition/state_aid /123013_en.htm (accessed on 5 January 2014).

82. European Union (EU). White paper on services of general interest. Communication from the Commission to the European Parliament, the Council, the European Economic and Social Committee and the Committee of the Regions: COM 0374 final, Brussels, Belgium, 2004. Available online: http://eur-lex.europa.eu/legal-content/EN/TXT/PDF/?uri=CELEX:52009DC0374 $\&$ from=EN (accessed on 5 January 2014).

83. Instituto Nacional de Estadística (INE). Household Budget Survey, INE, Madrid, Spain, 2013. Available online: http://www.ine.es/jaxi/menu.do?type=pcaxis\&path=/t25/p458\&file=inebase (accessed on 30 December 2014).

84. Instituto Nacional de Estadística (INE). Economically Active Population Survey. INE, Madrid, Spain 2014. Available online: http://www.ine.es/dyngs/INEbase/en/operacion.htm?c=Estadistica _C\&cid=1254736176918\&menu=ultiDatos\&idp=1254735976595 (accessed on 30 December 2014).

85. Instituto Nacional de Estadística (INE). Living Conditions Survey; INE: Madrid, Spain, 2014. Available online: http://www.ine.es/jaxi/menu.do?type=pcaxis\&path=/t25/p453\&file=inebase (accessed on 30 December 2014).

86. Giménez, M.; Babiano, L. El derecho humano al agua. El Ecologista 2014. Available online: http://www.ecologistasenaccion.org/article27970.html (accessed on 20 December 2014).

87. European Commission. Communication from the Commission on the European Citizens' Initiative Water and sanitation are a human right! Water is a public good, not a commodity, Brussels, Belgium, 19 March 2014. Available online: http://eur-lex.europa.eu/legal-content/ EN/TXT/?uri=celex:52014DC0177 (accessed on 5 January 2015).

88. European Economic and Social Committee (2014). Water and sanitation are a human right. In Opinion on the Communication from the Commission on the European Citizens' Initiative Water and Sanitation are a Human Right! Water is a Public Good, not a Commodity. Available online: http://www.eesc.europa.eu/?i=portal.en.nat-opinions.32450 (accessed on 5 January 2014).

89. Federación de Asociaciones de Consumidores y Usuarios de Andalucía (FACUA). Estudio comparativo sobre las tarifas del agua en 28 ciudades. Available online: http://facua.org/es/guias /estudio-tarifas-agua2013.pdf (accessed on 5 January 2014).

90. Organización de Consumidores y Usuarios (OCU). Precio del agua. Compra Maestra 2014, 390, $23-25$.

(C) 2015 by the authors; licensee MDPI, Basel, Switzerland. This article is an open access article distributed under the terms and conditions of the Creative Commons Attribution license (http://creativecommons.org/licenses/by/4.0/). 